\title{
ТЕМБР-АМПЛУА ЯК ОСНОВА МУЗИЧНОГО ОБРАЗУ У ВОКАЛЬНОМУ МИСТЕЦТВІ
}

\section{Оганезова-Григоренко О. В.}

\section{ВСТУП}

У загальному полі вивчення творчих процесів усе більша увага приділяється вивченню особливостей творчих алгоритмів за спеціалізаціями. У багатьох жанрах вокально-сценічної творчості одні й ті ж первісні інструменти - такі як вокальний голос - мають відмінні технології застосування та, відповідно, відмінні результати творчості, що зумовлені особливостями законів жанру. У цьому контексті пропонуємо звернутися до такого різнобічного художнього феномена, як тембр-амплуа вокаліста. У статті пропонується аналіз тембру-амплуа як особливого інструмента музичного висловлення вокаліста, який у різних жанрах має різне «поле вживання» та різні механізми реалізації.

Тембр-амплуа здатний у вокальному відображенні повноцінно втілити семантику характеру оперного персонажу, «упредметнює» у вокальному звуці тип особистості героя; спосіб його художнього мислення; особливості комунікації з глядачем...»1.

Спираючись на таке визначення, спробуємо надати характеристику феномену тембру-амплуа у різних вокально-сценічних жанрах: опері та мюзиклі.

Для того щоб пояснити специфіку народження співаком-артистом музичного образу на сцені, необхідно розуміти специфіку жанру, в якому працює співак. I розуміти треба не зовнішню, а саме внутрішню природу жанру, з точки зору виконавця, зсередини.

Почнемо вивчення проблеми з аналізу самої поетики цих вокальних жанрів.

У науковій літературі представлена велика кількість визначень терміна «поетика» стосовно не тільки літератури, а й інших творчих жанрів. Фокус нашої уваги спрямований на розуміння поетики вокального жанру як сукупність виразних засобів, що роблять твір гармонійним та надають можливості усвідомити художній світ автора,

Авраменко Є.Б. Тембр-амплуа як інструмент вираження оперного «голосообразу» (на прикладі драматичного тенора). Музичне мистецтво у культура : науковий вісник ОНМА імені А.В. Нежданової / гол. ред. К. Фламм. Вип. 30 (1). Одеса : Видавничий дім «Гельветика», 2020. С. 94. 
а також як розуміння внутрішнього зв'язку мови жанру, як засобу художньої комунікації та свідомості виконавця.

Таким чином, визначаємо дві вихідні аналізу феноменології тембруамплуа у вокальній творчості: поетика жанру (жанрові закони та традиції) та інструменти втілення авторського задуму виконавцем (комунікативна мова жанру).

У цьому контексті розглянемо специфіку «сценічного існування» (термін школи К.С. Станіславського) вокаліста в опері та мюзиклі для того, щоб пояснити сутність поняття «тембр-амплуа» у цих жанрах, визначити відмінності та пояснити, яким чином тембр-амплуа виступає як інструмент втілення на сцені авторського задуму у різних вокальносценічних жанрах.

Таке пояснення $є$ необхідним у визначенні характеру музичного образу та інструментів його втілення у різному жанровому матеріалі, а також для успішного прогнозування творчої кар’єри вокаліста.

\section{1. Аналіз комунікативної функції тембру-амплуа у різних вокально-сценічних жанрах}

Отже, жанр опери передбачає комунікацію особливого характеру, в певному розумінні таку, що не потребує когнітивної роботи, первісно заточену таким чином, що глядач на позасвідомому рівні сприймає та впізнає сутність та перспективу драматургічного розвитку завдяки розмаїттю барв людського голосу. Іншими словами, глядачу в опері не потрібно домислювати, аналізувати, будувати логічні ланцюжки музика первісно надає все розуміння смислів, характерів та взаємин персонажів. Інформація опери здатна бути сприйнятою глядачем на інтуїтивному рівні.

Таким чином, в опері повинен бути присутнім такий інструмент виразовості, який здатен втілити авторський задум повною мірою. I цей інструмент - голос.

Оперний співак характеризується особливим типом вокальних даних, що дозволяє розвити голос до певного діапазону і певного рівня звукової емісії за оркестрового супроводження без звукових втрат. Крім цього, голос оперного співака повинен мати певні висотні характеристики відповідно до загальної типології голосів: сопрано, мецо-сопрано, контральто, тенор, баритон, бас.

Але жанр опери передбачає не тільки належність до певного типу голосу, але й обов'язкову особливу тембральну забарвленість голосу.

Усі оперні партії мають досить «вузький коридор» виконавців. Композитор творить музичну партитуру, виходячи 3 того, що певну партію буде виконувати голос із строго визначеними якостями висотними: сопрано, мецо-сопрано, контральто, тенор, баритон, бас; 
та вираженим тембром-амплуа - такою визначною барвою голосу, саме яку автор програмує для втілення художніх та музичних завдань образу у загальному контексті твору.

Тембр-амплуа - своєрідний «підтип» оперного голосу, який виступає «куратором» художніх завдань персонажів оперної вистави. Вокаліст, який є втілювачем музичного образу, не може мати інший тембр-амплуа, ніж це передбачено композитором: драматичний голос не може втілювати ліричну партію - «барва» персонажу у загальній музичній палітрі твору повинна бути строго певною, і саме цю барву здатний втілити голос строго певного тембру-амплуа. Зауважимо, що в опері тип голосу - сопрано, мецо-сопрано, контральто, тенор, баритон, бас - несе лише загальний контур образу, а тембр-амплуа виступає як розгорнута психологічна характеристика загального типу голосу у конкретному музично-драматургічному контексті - у конкретній опері. Отже, тембр-амплуа - це своєрідне «психологічне тавро» персонажу в опері. Якщо тембр голосу людини взагалі $є$ певним інструментом вираження сутності особистості ${ }^{2}$, то в опері тембр голосу вокаліста $\epsilon$ інструментом персоніфікації сценічного образу. Отже, в оперному мистецтві музичний образ народжується завдяки саме тембру-амплуа. Саме тембр-амплуа «упредметнює» в звуці тип особистості оперного персонажу.

Типологія тембрів-амплуа в опері грунтується на принципах експресивності та натуральності голосів. Таким чином, тембр-амплуа це не сформована навичка вокального апарату, а природна характеристика голосу.

Розмежування тембрів-амплуа у рамках одного типу голосу має й технологічний складник: голос оперного соліста має звучати у певній теситурі, у оркестровій партитурі певної щільності, при цьому його повинно бути добре чутно у всіх куточках глядацької зали. До того ж солісту необхідно проспівати 3-4 години, при цьому зберегти вокальний апарат здоровим. Таким чином, логічно дійти висновку, що тембр-амплуа - це не просто барва голосу, а і його психофізичні можливості та характеристики.

Отже, задля більш повного розуміння феномена тембру-амплуа в опері пропонуємо триєдине бачення функціонального навантаження тембру-амплуа в опері:

- авторське - точно прогнозована художньо-звукова барва у загальній палітрі твору;

2 Манёров В.Х. Психодиагностика личности по голосу и речи. Санкт-Петербург : Изд-во РГПУ им. А.И. Герцена, 1999. 96 с. 
- глядацьке - певний характер персонажу (ліричний, драматичний, характерний тощо) пізнається через певний тип тембру-амплуа;

- виконавське - тембр-амплуа певного вокаліста - фізичні та психофізіологічні характеристики його апарату, які він знає, у відповідності до яких користується своїм вокальним апаратом.

Послідовно розберемо ці три позиції.

В оперному мистецтві, як особливому жанрі, 3 одного боку, втілюється найвищий ступінь умовності сценічної дії - спів замість мови, а з іншого - опера є полем дуже «чітко окресленого» розуміння персонажу й, відповідно, трактовки драматургічного конфлікту. Таке жорстке окреслення «поля маневру» для постановників та виконавців визначає музичний матеріал, який не дає можливості вільно трактувати драматургію твору. Музика «консервує» розуміння та загальноприйняту трактовку оперного матеріалу. На відміну від театру драматичного, в опері не можна змістити або переформатовати драматургічний конфлікт. Він $\epsilon$ «законсервованим» у музичному матеріалі. Тому режисерські експерименти в опері виглядають мало переконливими: що б не «склав» режисер, він не зможе переформатувати зміст та смисли, закладені у музиці. Саме тому режисерські експерименти в академічних операх зводяться до переносу діï у часі (наприклад, із Середньовіччя на сучасний соціум) або переносу місця дії у інші побутові умови (наприклад, 3 палацу в офіс або на корабель). Отже, особливістю опери $є$ певна консервативність постановочної трактовки.

Будь-який сценічний театральний жанр, i опера у тому числі, потребує від виконавця певної сценічної «маски» - перетворення виконавця у певний образ, перетворення особистості виконавця в умовну особистість музичного образу. Але в опері перетворення особистості артиста на особистість персонажу, порівняно 3 драматичним театром або театром мюзиклу, є вельми умовним. У драмі та мюзиклі актор, перетворюючись, моделює свій тембр голосу. При цьому відбувається це не завжди свідомо. Акторський апарат артиста мюзиклу складений таким чином, що тембр голосу здатний змінюватись до невпізнання залежно від сценічних завдань персонажу. Голос артиста мюзиклу - це інструмент, який відображує перетворення особистості артиста на певну роль-образ - іншу особистість. Таким чином, тембр голосу артиста та тембр голосу ролі-образу у мюзиклі це різні тембри.

В опері закони жанру та технології виконання інші. В опері тембр голосу як основна барва персонажу є незмінним.

Іншими словами, тембр голосу оперного персонажу не є результатом акторського перевтілення, а $є$ первісно заданою характеристикою голосу 
оперного виконавця. Таким чином, голос оперного співака не відображує акторський процес перевтілення особистості виконавця в особистість музичного персонажу. Особистість музичного образу вже відображено саме у тембрі-амплуа оперного голосу. Функція тембруамплуа в опері - саме втілення характеру через відповідність свого підтипу голосу авторському задуму. Тембр-амплуа, за великим рахунком, є заміною в опері акторському перевтіленню. А якщо так, то логічним $є$ висновок про те, що інструментом створення музичного образу в опері - так званої «оперної маски» - $\epsilon$ виключно тембр-амплуа співака, який завжди є однаковим. Саме тому стосовно тембру-амплуа в опері ми говоримо не про народження музичного образу (як процесу перетворення особистості виконавця), а про втілення авторського задуму через тембр-амплуа. Іншими словами, психофізичний апарат оперного співака не переживає трансформацію особистості на кшталт драматичного актора або артиста мюзиклу. Тип голосу, тембр голосу, манера співу - це константні складники. Тому комунікація оперного жанру передбачає не перевтілення виконавця, а первісно завдані психофізіологічні дані голосу співака - його тембр-амплуа, який $\epsilon$ незмінним.

У мюзиклі, завдяки «переродженню» особистості артиста у особистість ролі-образу, голос і тембр набувають зовсім неочікуваних, невластивих барв. Пояснення цього явища полягає у самій жанровій природі мюзиклу та у технологічних особливостях комунікації жанру.

Артист у мюзиклі - це актор-музикант. Його голос перетворюється так само, як і його внутрішній акторський стан, як його пластика.

В опері ж таке перевтілення є вельми умовним. В опері практично відсутня робота над роллю у класичному акторському алгоритмі: нема «маски», $€$ харизма співака, яка проявляється у різноманітному матеріалі по-різному. Отже, оперний співак у ролі - це «Я у запропонованих обставинах», а не «Я - інший» ${ }^{3}$.

Акторський алгоритм оперного співака $є$ досить простим та коротким: оперний співак не займається формулюванням завдань, дій та реалізацією інших сходинок акторського алгоритму. Тому $\epsilon$ пояснення: насамперед чітка «окресленість» музичної характеристики оперного образу не передбачає будь-якого переломлення авторського матеріалу особистістю виконавця. В опері важливе й потрібне лише втілення авторського задуму співаком певного тембру-амплуа. I це втілення спирається на природу голосу вокаліста, а не на творчий механізм перевтілення в іншу особистість, як у драмі або мюзиклі.

\footnotetext{
${ }^{3}$ Станиславский К.С. Работа актера над собой, ч. 1: Работа над собой в творческом процессе переживания. Дневник ученика. Москва : Искусство, 1985. 479 с.
} 
В опері закони процесу народження образу мають дещо іншу основу: сама природа безперервного музичного викладення не потребує від співака зусиль з просування до реалізації завдань ролі. До цієї реалізації приведе розвиток музичної партитури. Справа співака просто «плисти за течією» музичного викладення. Власне, процес акторського розвитку ролі в опері заміняс тембр-амплуа співака. У тембрі-амплуа вже закладено характер персонажу (комічний, ліричний, драматичний), його тип темпераменту (сильний чи слабкий), його головна драматургічна дія (творення, розв'язання конфлікту чи загострення конфлікту, руйнування тощо).

Отже, якщо характер персонажу визначає тембр-амплуа, який закладено композитором у музичній партитурі, а тембр-амплуа - це природна характеристика голосу, то можна зробити висновок, що опера не потребує процесу перетворення особистості виконавця, досить того, що тембр-амплуа співака співпадає з авторським задумом.

Барви голосу певного тембру-амплуа втілять характер оперного героя поза будь-яким перетворенням особистості співака. Тому оперний образ $\epsilon$ постійним та не підлягає змінам трактування. Саме рішення вистави може бути парадоксальним, але типовість вокально-сценічного образу не зміниться - у рамках музичної партитури це просто неможливо, тому що теситура вокальної лінії, щільність оркестрової партитури та інші специфічні особливості музичного матеріалу не дозволять іншому типу голосу (навіть іншому тембру-амплуа того ж типу голосу) переконливо прозвучати у такому матеріалі.

Наприклад, партія Тетяни в опері П.І. Чайковського «Свгеній Онєгін» написана для ліричного сопрано. Якщо виконавиця партії має тембрамплуа драматичного сопрано, вона може переконливо прозвучати в останній сцені-прощанні з Онєгіним, але музичний матеріал першого акту - Сцена листа - набуде барв голосу дорослої досвідченої жінки, що притаманне тембру-амплуа драматичного сопрано. Отже, загубиться первісний чуттєвий смисл образу - молода, захоплена першим коханням людина, яка вперше відчуває чуттєві коливання, з якими не може впоратись. До речі, і в останній сцені Тетяна, за задумкою і Пушкіна, i Чайковського, постає не дорослою людиною, що «пережила свої бажання», а такою ж захопленою трепетною дівчиною, як і у перші миті зустрічі зі своїм коханням. Отже, тембр-амплуа драматичного сопрано не відповідає смисловій задумці авторів. Так само й щодо використання у цій партії більш легкого голосу: тембральні барви легкого сопрано не можуть передати всю палітру першого любовного хвилювання героїні. Такий голос переконливий у матеріалі, що передбачає «блискучість», радість, ствердження, навіть кокетство, тобто зовсім інший психотип героїні. Повторюємо, йдеться про головний інструмент оперного 
мистецтва - тембр голосу, який первісно задає і характер героя, і тип його сприйняття глядачем. До того ж оркестрова партитура, що передбачена для ліричного сопрано, відрізняється від оркестрової партитури, кращої для драматичного або для легкого сопрано. В оркестровій партитурі завжди щільність звучання оркестру, тембральні барви інструментів, що використовуються у такому матеріалі, $\epsilon$ гармонічними щодо певного типу тембру-амплуа. Спроби відійти від цього загального правила руйнують усю драматургічну конструкцію оперного твору та порушують «правила комунікації» оперного театру як особливого жанру сценічного мистецтва.

С ще один складник пояснення тембру-амплуа як найголовнішого інструмента виразовості в опері як певного замінювача акторської дії, що передбачено самою поетикою жанру. Будь-який сюжет на сцені - це розвиток подій. Сутність будь-якого драматургічного твору відображення трансформації персонажа від первісного стану до нового самовідчуття. Шлях до набуття цього нового - драматургічна дія, що є центральним поняттям будь-якого сценічного жанру. Але специфіка опери полягає саме в тому, що розвиток сюжету відбувається поза основними опорними точками опери: ані арія, ані дует, ані ансамбль не $\epsilon$ «полем дії». Будь-який музичний номер опери - це усвідомлення та осмислення героєм якогось стану, причому сильно розтягнуте у часі. За великим рахунком, музичні номери опери гальмують розвиток подій, фокусуючи увагу глядача на «застиглому» переживанні героя, що відображено та детально розцвічене з різних боків виключно тембром голосу співака. А розвиток подій перенесено у речитативні частини, що $\epsilon$ лише проміжними зв'язками між музичними номерами. Таким чином, поетика опери передбачає акцент не на подіях або вчинках героїв, а на звуковому відображенні рефлексії героїв 3 приводу дій та вчинків. Отже, в опері «факт дії реалізується через звучання» ${ }^{4}$. Іншими словами, «внутрішня дія» персонажу (термін акторської школи К.С. Станіславського) реалізується звуковим інструментом - не просто голосом, а певним тембром-амплуа голосу, а характеристики тембруамплуа відіграють визначальну роль у реалізації авторського задуму. Відповідно, можна зробити висновок, що тембр-амплуа виступає як первісна основа всебічної реалізації жанрової специфіки опери як сценічного мистецтва.

Якщо «спростити» проблему - в опері драматичні та трагічні образи реалізують голоси драматичного тембру-амплуа, ліричні відповідно. Таким чином, тембр-амплуа у певному розумінні можна розглядати як

4 Самойленко О.І. Психологія мистецтва: сучасні музикознавчі проєкції : монографія. Одеса : Видавничий дім «Гельветика», 2020. 236 с. 
проєкцію психотипу персонажа, на кшталт драматичного театру, де проєкцією психотипу персонажу $є$ амплуа актора. I якщо в драматичному театрі успіх втілення сценічного образу визначає точний вибір на роль актора певного амплуа, то в театрі оперному цю невловиму, але дуже вагому складову частину загальної успішності творчого продукту несе тембр-амплуа співака.

Слід зазначити, що тембр-амплуа також відіграє визначальну роль у глядацькому сприйнятті персонажа. Тембральні барви голосу вокаліста одразу налаштовують глядача на певне сприйняття музичного образу: якщо це ліричний голос, то глядач одразу відчуває, що персонаж має характер м'який, скоріш за все у драматургічному розвитку він буде втілювати любовну лінію, лінію молодих почуттів, юного сприйняття життя, беззахисності перед труднощами тощо. Якщо ж глядач чує тембральні барви драматичного голосу, він позасвідомо готується до конфліктної ситуації, до страждань героя, до боротьби, можливо, до сприйняття героя як негативного персонажа - злодія тощо. Первісність, архетипність такого позасвідомого сприйняття тембральних барв людського голосу має багато описів та обгрунтувань у науковій, популярній літературі, навіть у методичній вокальній літературі ${ }^{5,6,7}$.

Отже, тембр-амплуа безпомилково прогнозує глядацьке

\section{сприйняття.}

На відміну від артистів мюзиклу, для яких можливе значне розширення тембральної палітри голосу завдяки використанню мікрофона та законів жанру, що мають інші пріоритети та способи комунікації, для оперного співака практично неможливим $є$ вихід за межі тембральної палітри свого типу голосу - найтонше нюансування та оперна «понад-оркестрова» емісія вокального звуку є несумісними. Відповідно, оперний співак завжди перебуває у межах свого типу голосу та свого тембру-амплуа. Іншими словами, виражений тембрамплуа у певному розумінні обмежує творчий потенціал конкретного оперного співака.

До речі, так звані «проміжні» голоси - mittelstimme - в опері $є$ менш конкурентоспроможними, ніж голоси вираженої належності до певного тембру-амплуа. Поле втілення «проміжних голосів» в опері є набагато вужчим, ніж у їхніх «певних» собратів. А у камерному вокальному

5 Кирнарская Д.К. Психология специальных способностей. Музыкальные способности. Москва : Таланты - XXI век, 2004. 496 с.

${ }^{6}$ Северинова М.Ю. Архетипи в культурі у проєкції на творчість сучасних українських композиторів : дис.... д-ра мистецтвозн. : 26.00.01. НМАУ ім. П.І. Чайковського. Київ, 2013. 415 с.

7 Емельянов В.В. Развитие голоса. Координация и тренинг: учебное пособие. Санкт-Петербург : Лань, 2004. 192 с. 
мистецтві навпаки. Менш виражена «типовість» голосу надає більш широкі можливості для трактування музичного матеріалу. У камерному вокальному мистецтві співак перебуває у більш «сприятливих» умовах: емісійно-голосові вимоги до виконавця відходять, тому що чутність співака $є$ результатом скоординованої роботи з концертмейстером, який повинен враховувати характеристики голосу свого соліста та корегувати щільність подання акомпанементу. Крім того, у камерному співі більший успіх мають голоси неясного тембру-амплуа, тому що саме така неясність надає можливості працювати над самим різноманітним та різножанровим матеріалом та навіть у рамках одного твору використовувати набагато більшу палітру виконавських барв.

3 точки зору внутрішнього творчого процесу оперного співака треба закцентувати ще один важливий аспект розуміння феномена тембруамплуа. Левову частку сценічної енергії, експресивності виконання оперному співаку надає не переживання музично-драматичного матеріалу, а «занурення» у власне звучання.

3 одного боку, таке «занурення» збіднює когнітивний процес виконавця (у загальноприйнятому розумінні творчого процесу актора, який заздалегідь вибудовує не тільки поведінку свого персонажу, але й напрям та розвиток думки свого персонажу), але з іншого - саме у цьому зануренні у власне звукоутворення є особлива феноменологія співу та оперного співу зокрема.

Відчуття власного голосу, відчуття його тембральних барв повністю підкорює собі увесь алгоритм сценічного існування вокаліста. Чуйність співака, як іiі сприймають глядачі, включається не інтонаційною семантикою музичного матеріалу, а i фізіологічним відчуттям тембральних барв власного голосу. Простіше кажучи, чуйність співу народжується не у переживанні музики, а у переживанні відчуття власного голосоутворення.

Отже, тембр-амплуа співака треба розглядати не просто як даний природою голос, а як результат переплетення всіх характеристик живого організму співака - фізіологічних та психофізіологічних здібностей.

Зокрема, у тембрі-амплуа опосередковано відображено тип темпераменту вокаліста. Отже, забарвленість голосу у певному розумінні виступає як зовнішній прояв швидкості та інтенсивності внутрішніх процесів співака. Відповідно, саме у тембрі-амплуа втілюється «психологічна природа» не тільки музичного образу, а й співака-особистості.

На підтвердження цього проведене анкетування оперних співаків, яке дало вельми дивний результат: представники різних типів голосів, але одного тембру-амплуа (драматичний або ліричний) реагували на 
опитування подібним образом. Наприклад, для драматичних сопрано, тенорів та баритонів притаманна налаштованість на оцінювання свого бачення сценічного образу як остаточне та правильне, тобто можна прослідити загальну налаштованість співаків драматичного тембруамплуа на відстоювання своєї позиції, якщо не на конфлікт 3 режисером або диригентом, то хоча б на рівне співробітництво, на те, що їхня думка буде врахована; а для ліричних голосів - тенора, сопрано, баритона - притаманна налаштованість на підкорення волі режисера, диригента, первісна налаштованість у спілкуванні на рішення, «спущене зверху» тощо. Таким чином, результати опитування опосередковано підтверджують, що тембр-амплуа $\epsilon$ не тільки відображенням психотипу музичного образу, але й відображенням психотипу особистості самого співака.

А це підтверджує, що певний тип тембру-амплуа передбачає певний тип темпераменту.

Багаторічний педагогічний досвід дає можливість узагальнити, що невідповідність фізіологічних характеристик голосу - тембру-амплуа та типу темпераменту, а таке часто-густо трапляється, не дозволяє прогнозувати професійну кар'єру оперного співака. Вокаліст 3 такими «невідповідностями» просто не зможе витримати емоційне та технічне навантаження музичного матеріалу для свого типу голосу та свого типу тембру-амплуа. Голосовий апарат як живий інструмент не може повноцінно озвучити свій тембр, якщо не має відповідної емоційної підтримки від усього організму співака. Певний тембр-амплуа потребує певного емоційного градуса від виконавця, який прогнозується типом темпераменту.

Отже, тембр-амплуа оперного співака $\epsilon$ біологічною характеристикою його голосового апарату та виступає інструментом реалізації музичного образу та правдивого втілення характеру оперного персонажу на сцені.

Точне використання певного тембру-амплуа стосовно певних партій $\epsilon$ визначальним фактором у реалізації авторського задуму композитора, точного сприйняття цього задуму глядачем та успішного «сценічного існування» (термін акторської школи К.С. Станіславського) самого вокаліста в оперній виставі взагалі. Отже, тембр-амплуа вокаліста та тип його темпераменту перебувають у прямій залежності.

А якщо голос вокаліста $\epsilon$ способом індивідуалізації та персоніфікації вокально-сценічного образу, то завдяки певному типу тембру-амплуа народжується певний смислообраз в опері. Саме тому типологія тембрів-амплуа базується на принципах експресивності та натуральності голосів, що $є$ опосередкованим втіленням у вокальному мистецтві принципів театру реалізму К.С. Станіславського - 
правдивість сценічного образу в опері визначається насамперед відповідністю тембру-амплуа музичній семантиці матеріалу.

\section{2. Порівняльний аналіз художньої виразовості тембру-амплуа у різних вокально-сценічних жанрах на прикладах}

Тембр-амплуа «упредметнює» у вокальному звуці тип особистості героя, спосіб його художнього мислення, особливості комунікації 3 глядачем, $\epsilon$ втіленням технологічних особливостей звукоутворення певного типу голосу.

«Чуючи голос певного тембру та у певному регістрі, ми вже багато знаємо про те, що нам робити та чого чекати від цього звукового «джерела» ${ }^{8}$, - відзначає Д.К. Кирнарська. Таким чином, необхідно розуміти та враховувати, що саме тембр голосу співака є головним інструментом у вираженні смислів оперної вистави та точності сприйняття цих смислів глядачем.

Тембр-амплуа закріплює за голосом не тільки його основну емоційну характеристику, але й відображується у фактурі оркестрової партитури. Іншими словами, наповнення оркестрової партитури $\epsilon$ відповідним певному тембру-амплуа. Таким чином, оркестрова партитура, працюючи у гармонії з тембром-амплуа співака, допомагає голосу найбільш повно й точно виразити характер персонажу.

Наприклад, арія князя Слецького та Балада Томського з опери П.І. Чайковського «Пікова дама». Обидві партії написані для баритона, але Єлецький - для ліричного баритона, а Томський - для драматичного баритона. Відповідно, в оркестровій партитурі превалюють різні тембральні барви - різні оркестрові інструменти: в арії Єлецького - це гобой та віолончель, а у Баладі Томського - вся струнна група оркестру, при цьому, на відміну від арії Єлецького, оркестрова партія не просто поступово набуває тембрів струнних інструментів, але й «набуває» фактурної палітри оркестрового викладення: розмір, метроритм, акценти, тривалості тощо.

Єлецький - ліричний баритон, невеликий за «кількістю звуку», але здатний на втілення не яскравої пристрасті, а величезної палітри півтонів почуттів. Оркестрова партитура арії Слецького, відповідаючи ліричному тембру-амплуа баритона, дає можливість голосу максимально повно виразити тонкі нюанси почуттів персонажа, при цьому комфортно існуючи 3 точки зору вічної боротьби вокаліста 3 емісією оркестрової партитури.

Балада ж Томського, навпаки, є втіленням відкритих пристрастей. Причому не самого персонажу Томського, а пристрастей головного

8 Кирнарская Д.К. Психология специальных способностей. Музыкальные способности. Москва : Таланты - XXI век, 2004. 496 с. 
героя - Германа. Вибір для партії Томського драматичного тембруамплуа диктує драматургічне навантаження цього персонажа у загальному контексті твору. Саме Балада пробуджує у душі Германа його демонів. Саме Балада $\epsilon$ «початком сюжету» для Германа. Саме цей «світський анекдот» назавжди отруює душу головного героя. I для того щоб точно передати містичність, спокусливість, передчуття загибелі у цьому «світському анекдоті», потрібен голос певного тембру, здатний на вираження барв певного характеру.

Трагічний зміст та глибинний смисл Балади Томського виступають як згусток сутності внутрішнього конфлікту Германа. Тільки конфлікт цей «озвучено» та втілено устами іншого персонажу. Якщо тембральна та артикуляційна палітра голосу Томського не зможе «закріпити» у свідомості глядача відчуття фатальності того, що відбувається, відчуття глобального настрою головного героя на саморуйнування - не відбудеться й втілення на сцені самого сюжету, самого головного драматургічного конфлікту твору. Отже, тембр-амплуа виконавця цієї партії має окреслені рамки. Точність драматургічного розвитку, смислового навантаження, емоційної атмосфери опери програмується саме Баладою Томського, тобто точністю тембру-амплуа виконавця цієї партії: буде це болісно бажаний шлях до фатального фіналу зруйнованої особистості або банальна історія про нещасливе кохання та невезіння у грі.

Для прикладу, проаналізуємо виконання Балади Томського Дмитром Хворостовським та Владиславом Сулімським (ці та інші відеоматеріали можна знайти на платформі YouTube).

У виконанні Д. Хворостовського сам персонаж Томський представлений перед глядачем таким собі світським левом, аристократом, який розповідає «світський анекдот». Сам голос співака, його тембр-амплуа - ліричний баритон викликає у глядача відчуття упорядкованості та визначеності думок, почуттів. Такий голос «бентежить» лише відвертими почуттями, у ньому відсутні барви зради, омани, прихованого смислу. Тембр-амплуа ж В. Сулімського драматичний баритон, навпаки, одразу викликає чуття потаємної сили, що як демон рветься з глибин назовні, викликає позасвідому тривогу, передчуття чогось фатального, невідворотного, якоїсь страшної драми, що повинна розвернутися перед глядачем.

Таким чином, для партії Томського необхідний тембр-амплуа саме драматичного баритона, голосу, що здатний найбільш повно та точно втілити драматургічне навантаження цього персонажу у сюжеті опери. А тембр-амплуа ліричного баритона знижує «первісні умови» конфлікту, не дає глядачу того самого звукового передчуття розвитку сюжету, що притаманне жанру опери. Зав'язка сюжету буде представлена глядачу літературним текстом Балади, але інтродукція драматургічного сюжету не прозвучить у головній комунікації опери - вокальному звуці. А ось у партії 
Єлецького тембр-амплуа Д. Хворостовського ідеально втілює сутність персонажу, його внутрішній світ та його драматургічне навантаження у загальному контексті сюжету.

Наведемо ще один приклад того, як тембр-амплуа впливає на сприйняття глядачем оперного героя. Партія Алеко 3 опери С.В. Рахманінова «Алеко» виконується як баритонами, так і басами. Але різні тембри-амплуа народжують зовсім різні образи героя. Розглянемо цю арію на прикладі виконання Д. Хворостовського та I. Абдразакова.

У виконанні Д. Хворостовського - баритона образ Алеко предстає як особистість молодого, пристрасного чоловіка, здатного на вбивство через ревнощі. Голос звучить по-молодому гаряче, яскраво чутні нотки сексуального наповнення, інколи звучання навіть зле, металеве. Його любовна пристрасть нагадує пристрасть-ревність Отелло.

У I. Абдразакова - баса завдяки іншому тембру-амплуа народжується зовсім інший музичний образ. Для такого Алеко Земфіра - це остання любов, у його коханні більше ніжності, ніж пристрасті. Фраза «Земфира... как она любила...» у І. Абдразакова звучить ніжно, болісно, в ній спогади про втрачені надії, ніж обурення. У Д. Хворостовського ця фраза звучить як звукова ілюстрація обурення, зародження ревності, підозри. А остання фраза «Моя Земфира охладела!» озвучують ці два голоси зовсім по-різному: у Д. Хворостовського - це рик раненого лева, пристрасний стон людини, серце якої розриває ревність, злість, бажання розірвати світ від свого безсилля; а у І. Абдразакова - це плач дорослої людини, життя якої втратило сенс. Його туга за Земфірою більш схожа на втрату своєї дитини. Отже, втілення одного й того ж матеріалу різними тембрамиамплуа народжує зовсім різні звукові, а значить і сценічні образи.

Таким чином, тембр-амплуа виступає як інструмент «внутрішнього портретування» " (О.І. Самойленко) оперного образу. Отже, в опері важливими є питання: «Що» - який саме образ планується створити на основі музичної партитури, та «Хто» - ідеальна модель артиста для цієї ролі, але відсутнє питання «Як»- тембр-амплуа, що задуманий для певної оперної партії «спрацьовує» як слухняний інструмент у процесі розкриття авторського задуму ${ }^{10}$.

У мюзиклі ж ідеться не про тембр-амплуа голосу, а про тембрамплуа певного персонажу. Поетика жанру мюзиклу зумовлює

9 Самойленко О.І. Психологія мистецтва: сучасні музикознавчі проєкції : монографія. Одеса : Видавничий дім «Гельветика», 2020. 236 с.

10 Наумов А.В. Понятие амплуа в практике оперного театра. $K$ постановке проблемы «Наука вчера, сегодня, завтра» : материалы IV международной заочной научно-практической конференции (18.09.2013), Россия, Новосибирск. URL: https://sibas.info/conf/science/iv/33953_(дата звернення: 25.03.2020). 
народження тембральних барв голосу завдяки акторським завданням та особливостям психофізики артиста, а також технологічним засобам комунікації, що використовуються у мюзиклі.

На відміну від артиста опери, для артиста мюзиклу нема ідеального вокального звучання: ідеальним звуком у мюзиклі $\epsilon$ той звук, що найбільш повно втілює емоцію, а наскільки він $€$ академічним та притаманним певному стилю вокалізації - не так важливо. Крім того, у мюзиклі використовується мікрофон, що значно розширює звукову та темброву палітру артиста: можна використовувати не тільки спів як такий, але й «архетипні звуки» - стогнання, хрип, ричання тощо. Отже, у мюзиклі, на відміну від опери, тембр-амплуа не є застиглою характеристикою персонажу, а є похідною від акторських завдань у загальному контексті певної постановки та психофізики самого артиста - його акторського амплуа.

Наприклад, музичний номер "Music of the Night" у виконанні різних артистів звучить зовсім по-різному, народжуючи зовсім різні за характером та смислом образи.

Джеральд Батлер у відомому фільмі «Привид опери» подає образ Привида як одинокої людини, майже дитини за світовідчуттям, яка сама собі творить фантазійний світ, в якому іiі кохають, в якому вона потрібна, в якому є рідна душа. Тому барви голосу Джеральда Батлера юні, любовні, повні пестощами, як у молодої людини, яку роздирає пристрасть та ніжність одночасно. Його голос звучить тембрально чисто, без архетипних призвуків, уособлюючи у звуці чистоту душі героя, відчутність у відносинах із Христиною «подвійних планів», повну довіру героя до предмета свого кохання.

У виконанні Кольма Вількінсона Привид - страшний старець, який лякає героїню, який підкорює іiі душу жахом, невідомістю, а не любов'ю (на відміну від виконання Джеральда Батлера), який бажає підкорювати героїню своїй волі. У цьому рішенні образу Привида нема місця коханню, ніжності, $є$ лише протистояння реальних людей та ворожих до них містичних сил. Голос виконавця металевий, насичений архетипними звуками - шепотом, навіть шипінням, хрипами і т. ін., що народжує своїм звучанням образ не людини, а жахливої істоти, яка вторгається у світ героїні, затягуючи ï у диявольські тенета.

Визнане класичним виконання Майкла Кроуфорда, до речі, першого виконавця ролі Привида, несе зовсім інше смислове наповнення: його Привид - це містична Душа Театру, яка любить героїню, але не людською любов'ю, а коханням Всесвіту Театру, таким собі коханням містичного Божества, яке веде свою «дитину» - актора до розкриття містерії музичної Душі. У виконанні Кроуфорда Душа Театру звучить зі спокійною силою, впевнено, у одній фразі переливаючись та 
розквітчуючись усіма барвами та смислами, від ясних, сонячних до темних, потаємних. Таке виконання уособлює звучання Божества, Надлюдини, когось такого, хто не підвладний навіть точному опису.

Для контрасту наведемо ще виконання цього музичного номера Андреа Бочеллі. У Бочеллі у співі не народжується образ Привида, $є$ просто спів красивого від природи голосу - тенора, який виконавець із задоволенням відчуває, що притаманне оперному співаку. Але якщо в опері тембр-амплуа апріорі втілює характер героя, то у мюзиклі просто голосу, який він $\epsilon$, у первісному стані не досить. Музичний матеріал цього жанру передбачає активне втручання у трактування авторського музичного тексту особистості актора.

\section{ВИСНОВКИ}

Феномен «тембру-амплуа» голосу вокаліста як механізм жанрової комунікації у різних музично-сценічних жанрах працює по-різному: в опері музичний образ втілюється за допомогою тембру-амплуа співака без додаткового акторського алгоритму, він $є$ первісною, заданою автором характеристикою оперного персонажу. У мюзиклі тембрамплуа виступає як результат акторського алгоритму, що реалізовано через специфіку психофізичного апарату конкретного артиста. Голос артиста мюзиклу змінює свої барви у відповідності до акторських завдань такого сценічного втілення. Отже, у мюзиклі тембр-амплуа є інструментом вираження акторського алгоритму, іншими словами, може бути змінним залежно від контексту рішення вистав. В опері тембр-амплуа задає цей контекст, залишаючись незмінним та реалізуючи авторський задум відповідно до поетики жанру.

\section{АНОТАЦІЯ}

У статті пропонується аналіз тембру-амплуа як особливого інструмента музичного висловлення вокаліста, який у різних жанрах має різне «поле вживання» та різні механізми реалізації. Для того щоб пояснити специфіку народження співаком-артистом музичного образу на сцені, необхідно розуміти специфіку жанру, в якому працює співак. I розуміти треба не зовнішню, а саме внутрішню природу жанру 3 точки зору виконавця, зсередини. Визначаємо дві вихідні аналізу феноменології тембру-амплуа у вокальній творчості: поетика жанру (жанрові закони та традиції) та інструменти втілення авторського задуму виконавцем (комунікативна мова жанру). Таке пояснення необхідне у визначенні характеру музичного образу та інструментів його втілення у різному жанровому матеріалі, а також для успішного прогнозування творчої кар'єри вокаліста. 
Тембр-амплуа - своєрідний «підтип» оперного голосу, який виступає «куратором» художніх завдань персонажів оперної вистави. Вокаліст, який є втілювачем музичного образу, не може мати інший тембр-амплуа, ніж це передбачено композитором: в опері тип голосу сопрано, мецо-сопрано, контральто, тенор, баритон, бас - несе лише загальний контур образу, а тембр-амплуа виступає як розгорнута психологічна характеристика загального типу голосу у конкретному музично-драматургічному контексті - у конкретній опері. Отже, тембрамплуа - це своєрідне «психологічне тавро» персонажу в опері. Саме тембр-амплуа «упредметнює» в звуці тип особистості оперного персонажу.

Типологія тембрів-амплуа в опері грунтується на принципах експресивності та натуральності голосів. Таким чином, тембр-амплуа це не сформована навичка вокального апарату, а природна характеристика голосу, що передбачає і його психофізичні можливості та характеристики. Задля більш повного розуміння феномена тембруамплуа в опері пропонуємо триєдине бачення функціонального навантаження тембру-амплуа в опері:

- авторське - точно прогнозована художньо-звукова барва у загальній палітрі твору;

- глядацьке - певний характер персонажу (ліричний, драматичний, характерний тощо) пізнається через певний тип тембру-амплуа;

- виконавське - тембр-амплуа певного вокаліста - фізичні та психофізіологічні характеристики його апарату, які він знає, у відповідності до яких користується своїм вокальним апаратом.

Тембр-амплуа в опері замінює процес акторського алгоритму. У тембрі-амплуа вже закладено характер персонажу (комічний, ліричний, драматичний), його тип темпераменту (сильний чи слабкий), його головна драматургічна дія (творення, розв'язання конфлікту чи загострення конфлікту, руйнування тощо). Отже, опера не потребує процесу перетворення особистості виконавця, досить того, що тембрамплуа співака співпадає 3 авторським задумом. «Внутрішня дія» персонажу реалізується звуковим інструментом - голосом певного тембром-амплуа голосу, а характеристики тембру-амплуа відіграють визначальну роль у реалізації авторського задуму. Відповідно, тембрамплуа виступає як первісна основа всебічної реалізації жанрової специфіки опери як сценічного мистецтва.

Тембр-амплуа безпомилково прогнозує глядацьке сприйняття. У тембрі-амплуа опосередковано відображено тип темпераменту оперного вокаліста. Відповідно, саме у тембрі-амплуа втілюється «психологічна природа» не тільки музичного образу, а й співакаособистості. 
Типологія тембрів-амплуа базується на принципах експресивності та натуральності голосів, що $\epsilon$ опосередкованим втіленням у вокальному мистецтві принципів театру реалізму К.С. Станіславського.

Тембр-амплуа закріплює не тільки основну емоційну характеристику персонажа, але й відображується у фактурі оркестрової партитури. Наповнення оркестрової партитури $є$ відповідним певному тембру-амплуа. Оркестрова партитура, працюючи у гармонії 3 тембром-амплуа співака, допомагає голосу найбільш повно й точно виразити характер персонажу.

У мюзиклі ж ідеться не про тембр-амплуа голосу, а про тембр-амплуа певного персонажу. Поетика жанру мюзиклу зумовлює народження тембральних барв голосу завдяки акторським завданням та особливостям психофізики артиста, а також технологічним засобам комунікації, що використовуються у мюзиклі. На відміну від артиста опери, для артиста мюзиклу нема ідеального вокального звучання: ідеальним звуком у мюзиклі $€$ той звук, що найбільш повно втілює емоцію. Крім того, у мюзиклі використовується мікрофон, що значно розширює звукову та темброву палітру артиста. Отже, у мюзиклі, на відміну від опери, тембрамплуа не є застиглою характеристикою персонажу, а є похідною від акторських завдань у загальному контексті певної постановки та психофізики самого артиста - його акторського амплуа.

Феномен «тембру-амплуа» голосу вокаліста як механізм жанрової комунікації у різних музично-сценічних жанрах працює по-різному: в опері музичний образ втілюється за допомогою тембру-амплуа співака без додаткового акторського алгоритму, він $\epsilon$ первісною, заданою автором характеристикою оперного персонажу. У мюзиклі тембр-амплуа виступає як результат акторського алгоритму, що реалізовано через специфіку психофізичного апарату конкретного артиста. Голос артиста мюзиклу змінює свої барви у відповідності до акторських завдань такого сценічного втілення. Отже, у мюзиклі тембрамплуа $\epsilon$ інструментом вираження акторського алгоритму, іншими словами, може бути змінним залежно від контексту рішення вистав. В опері тембр-амплуа задає цей контекст, залишаючись незмінним та реалізуючи авторський задум відповідно до поетики жанру.

\section{SUMMARY}

The article offers to analyze the timbre-role as a special instrument of musical expression of the vocalist, who in different genres may have different "fields of application" and different mechanisms of implementation. In order to explain the specifics of the birth of the musical image on stage by a singer and artist, it is necessary to understand the specifics of the genre in which the singer works. And it is necessary to 
understand not the external, but the internal nature of the genre - from the point of view of the performer, from within. We define two initial analyses of the phenomenology of the timbre-role in vocal art: poetics of the genre (genre laws and traditions) and tools for the implementation of the author's idea by the performer (communicative language of the genre). Such an explanation is necessary in determining the nature of the musical image and the instruments of its embodiment in various genre material, as well as for the successful prediction of the vocalist's creative career.

The timbre-role is a kind of "sub-type" of the opera voice, which acts as a "curator" of the artistic tasks of the opera characters. A vocalist who is the embodiment of a musical image cannot have a different timbre-role than the composer provides: in opera the type of voice - soprano, mezzo-soprano, contralto, tenor, baritone, bass - carries only the general contour of the image, and the timbre-role acts as a detailed psychological characteristic of the general type of voice in a specific musical and dramatic context - in a particular opera. Thus, the timbre-role is a kind of "psychological brand" of the opera character. It is the timbre-role that "objectifies" the type of personality of the opera character in the sound.

The typology of timbres-roles in the opera is based on the principles of expressiveness and naturalness of voices. Thus, the timbre-role is not a formed skill of the vocal apparatus, but a natural characteristic of the voice, which presupposes its psychophysical capabilities and characteristics. In order to better understand the phenomenon of the timbre-role in the opera, we offer a threefold vision of the functional load of the timbre-role in the opera:

- of the author - accurately predicted artistic and sound colour in the general palette of the composition;

- of the audience - a certain character - lyrical, dramatic, characteristic, etc. - is known through a certain type of the timbre-role;

- of the performer - the timbre-role of a certain vocalist - physical and psychophysiological characteristics of his apparatus, which he knows and, according to which, uses his vocal apparatus.

The timbre of the role in the opera replaces the process of the actor's algorithm. The character's timbre already includes the character (comic, lyrical, dramatic), his type of temperament (strong or weak), his main dramatic action (creation, conflict resolution or conflict escalation, destruction, etc.). Thus, the opera does not require a process of transformation of the performer's personality, it is enough that the timbrerole of the singer coincides with the author's intention. The "inner action" of the character is realized by a sound instrument - the voice of a certain timbre-role of the voice, and the characteristics of the timbre-role play a decisive role in the realization of the author's idea. Accordingly, the 
timbre-role serves as the initial basis for the comprehensive implementation of the genre specificity of opera as a performing art.

The timbre-role unmistakably predicts the audience's perception. The role of the opera vocalist's temperament is indirectly reflected in the timbrerole. Accordingly, it is in the timbre-role that the "psychological nature" of not only the musical image but also the singer-personality is embodied.

The typology of timbres-roles is based on the principles of expressiveness and naturalness of voices, which is an indirect embodiment in the vocal art of the principles of the theatre of realism of K.S. Stanislavsky.

The timbre-role fixes not only the main emotional characteristic of the character, but also is reflected in the texture of the orchestral score. The content of the orchestral score corresponds to a certain timbre-role. The orchestral score, working in harmony with the timbre-role of the singer, helps the voice to most fully and accurately express the character.

In the musical, it is not about the timbre-role of the voice, but about the timbre-role of a certain character. The poetics of the musical genre determines the birth of timbre colours of the voice due to the acting tasks and features of the artist's psychophysics. As well as technological means of communication used in the musical. Unlike the opera artist, there is no perfect vocal sound for a musical artist: the ideal sound in a musical is the sound that most fully embodies emotion. In addition, the musical uses a microphone, which significantly expands the sound and timbre palette of the artist. Thus, in a musical, unlike the opera, the timbre-role is not a frozen characteristic of the character, but is derived from the actor's tasks in the general context of a certain production and psychophysics of the artist himself - his acting role.

The phenomenon of the "timbre-role" of the vocalist's voice as a mechanism of genre communication in different musical and stage genres works differently: in opera the musical image is embodied by the timbre-role of the singer without additional acting algorithm, it is the original characteristic of the opera character. In the musical, the timbre-role acts as a result of the actor's algorithm, which is realized through the specifics of the psychophysical apparatus of a particular artist. The voice of the musical artist changes its colours in accordance with the acting tasks of this stage embodiment. Thus, in the musical, the timbre-role is a tool for expressing the acting algorithm, in other words, it can be variable depending on the context of the performance. In opera, the timbre-role sets this context, remaining unchanged and realizing the author's idea in accordance with the poetics of the genre.

\section{ЛІТЕРАТУРА}

1. Авраменко С.Б. Тембр-амплуа як інструмент вираження оперного «голосообразу» (на прикладі драматичного тенора). Музичне мистеитво 
у культура : науковий вісник ОНМА імені А.В. Нежданової / гол. ред. К. Фламм. Вип. 30 (1). Одеса : Видавничий дім «Гельветика», 2020. C. $89-96$.

2. Емельянов В.В. Развитие голоса. Координация и тренинг : учебное пособие. Санкт-Петербург : Лань, 2004. 192 с.

3. Кирнарская Д.К. Психология специальных способностей. Музыкальные способности. Москва : Таланты - XXI век, 2004. 496 с.

4. Манёров В.Х. Психодиагностика личности по голосу и речи. Санкт-Петербург : Изд-во РГПУ им. А.И. Герцена, 1999. 96 с.

5. Наумов А.В. Понятие амплуа в практике оперного театра. К постановке проблемы «Наука вчера, сегодня, завтра» Материалы IV Международной заочной научно-практической конференции (18.09.2013), Россия, Новосибирск. URL: https://sibas.info/conf/science/ iv/33953 (дата звернення: 25.03.2020).

6. Самойленко О.I. Психологія мистецтва: сучасні музикознавчі проєкції : монографія. Одеса : Видавничий дім «Гельветика», 2020. $236 \mathrm{c}$.

7. Северинова М.Ю. Архетипи в культурі у проєкції на творчість сучасних українських композиторів : дис. ... д-ра мистецтвозн. : 26.00.01. НМАУ ім. П.І. Чайковського. Київ, 2013. 415 с.

8. Станиславский К.С. Работа актера над собой, ч. 1: Работа над собой в творческом процессе переживания. Дневник ученика. Москва : Искусство, 1985. 479 с.

\section{Information about the author:} Ohanezova-Hryhorenko O. V., Doctor of Arts, People's Artist of Ukraine, Professor at the Department of Solo Singing Odessa National A. V. Nezhdanova Academy of Music 63, Novoselskogo str., Odesa, Ukraine 